\title{
Statement of Foliar Fertilization Impact on Yield, Composition, and Oxidative Biomarkers in Rice
}

\author{
M. Pinciroli, ${ }^{\dagger}$ R. Domínguez-Perles, ${ }^{*}{ }^{\ddagger}$ ¿ Á. Abellán, ${ }^{\ddagger}$ V. Bultel-Poncé, ${ }^{\S}$ T. Durand, ${ }^{\S}$ J. M. Galano, ${ }^{\S}$ \\ F. Ferreres, ${ }^{,}$and Á. Gil-Izquierdo*, \\ ${ }^{\dagger}$ Department of Climate and Agricultural Phenology, Faculty of Agriculture and Forestry Sciences, National University de la Plata, \\ Street 60 and 119, 1900 La Plata, Buenos Aires Argentina \\ ${ }^{\ddagger}$ Research Group on Quality, Safety and Bioactivity of Plant Foods, Department of Food Science and Technology, CEBAS-CSIC, \\ University Campus of Espinardo, Edif. 25, 30100 Espinardo, Spain \\ ${ }^{\S}$ Institut des Biomolécules Max Mousseron, IBMM, UMR 5247, University of Montpellier, CNRS, ENSCM, 34093 Montpellier, \\ France
}

\begin{abstract}
In rice crops, fertilization is a naturalized practice, although inefficient, that could be improved by applying foliar fertilization. Phytoprostanes (PhytoPs) and phytofurans (PhytoFs) are products of $\alpha$-linolenic acid peroxidation, useful as biomarkers of oxidative degradation in higher plants. The objective was to determine the effect of the foliar fertilization on the concentration of PhytoPs and PhytoFs and its relationships with modifications of yield and quality of rice productions. It was described that the concentration of biomarkers of stress decreased with the application of foliar fertilization, being the response significantly different depending the genotypes and compound monitored. Moreover, fertilization did not modify significantly the parameters of yield $\left(961.2 \mathrm{~g} \mathrm{~m}^{-2}\right), 1000$ whole-grain $(21.2 \mathrm{~g})$, and protein content $(10.7 \%$ dry matter). Therefore, this is the first work that describes the effect of fertilization on PhytoPs and PhytoFs in rice genotypes and reinforces the capacity of these compounds as biomarkers to monitor specific abiotic stress, in this case, represented by nutritional stress.
\end{abstract}

KEYWORDS: Oryza sativa, foliar fertilization, genotypes, protein grain, phytoprostanes, phytofurans

\section{INTRODUCTION}

Rice crops play a central role in the population nutrition of more than half world population. ${ }^{1}$ In this regard, given the current growth pattern, the human world population could reach 9 billion people by 2050, which would require an augmentation of agricultural production. ${ }^{2}$ To overcome this new situation, plant nutrition research has been pointed out as crucial to meet food quality and safety requirements. ${ }^{3}$ The fact that at least $60 \%$ of the nowadays cultivated soils globally have several mineral problems, like toxicities or deficiencies, makes plant nutrition-based research a cutting-edge issue essential to meet the demand for massive increases in food production. ${ }^{3}$

When analyzing the most important constraints associated with agricultural production, it is found that, to date, most yield losses and inappropriate nutrient concentrations are due to abiotic stress caused by drought, salinity, extreme temperatures, and soil acidity, which deteriorate the composition of soils and, consequently, the nutritional status of plants. Efficient and sustainable use of natural resources, along with appropriate agronomic practices, is key to overcome the challenges of the increasing world population and resources shortage. Under such challenging situation, enhancing crops yield per unit area is the main goal in the field. ${ }^{4}$

In this frame, nitrogen $(\mathrm{N})$ fertilization is a widely adopted practice in conventional agriculture. This is of special relevance due to the management of irrigation water, responsible for the status of organic $\mathrm{N}$ into soils (concerning both concentration and molecular form) as well as the lack of consistent evidence on the optimal timing for its application. ${ }^{5}$ As an alternative, foliar spraying provides nutrients availability at the exact time when they are required by plants, reducing the time-lapse between application and absorption. Hence, when applied at panicle initiation, foliar spraying provides plants the essential nutrients required for obtaining an optimal number of grains per panicle. ${ }^{6}$ Besides, Waraich et al. demonstrated that the application of micronutrients reduces the toxicity of reactive oxygen species (ROS) due to an increase in the concentration of antioxidant enzymes, ${ }^{6}$ contributing to the protection and maintenance of the integrity and stability of the cell membrane. ${ }^{7}$

The production of ROS during photosynthesis is intensified due to a limited use of the light absorbed upon photosynthetic electron transport and fixation of $\mathrm{CO}_{2}{ }^{8}$ These radicals are unstable and react rapidly with other compounds in the separate cell compartments, causing cellular or tissue damage. To avoid this negligible situation, plant cells account with molecular tools to combat excessive ROS, maintaining the redox balance within physiological limits. However, biotic and abiotic stress may disturb this balance. ${ }^{9}$

In many plant species, $\alpha$-linolenic acid (ALA) constitutes the end point of fatty acid biosynthesis that is prone to react 
Table 1. Average Climatic Conditions in the Experimental Field ( $34^{\circ} 52^{\prime} \mathrm{S}, 57^{\circ} 57^{\prime} \mathrm{W}, 9.8 \mathrm{~m}$ of Altitude) during the Rice Crops Established in the Seasons 2016/2017 and 2017/2018

\begin{tabular}{|c|c|c|c|c|c|c|c|}
\hline \multirow[b]{2}{*}{ parameter } & \multicolumn{7}{|c|}{ month/year } \\
\hline & October & November & December & January & February & March & April \\
\hline $\operatorname{Tm}\left({ }^{\circ} \mathrm{C}\right)^{a}$ & 1.2 & 12.2 & 16.5 & 17.7 & 18.6 & 15.1 & 11.9 \\
\hline $\mathrm{TM}\left({ }^{\circ} \mathrm{C}\right)^{b}$ & 20.1 & 24.4 & 28.6 & 28.5 & 28.4 & 25.4 & 22.4 \\
\hline $\mathrm{RH}(\%)^{c}$ & 75.0 & 61.0 & 57.0 & 65.0 & 76.0 & 69.0 & 70.0 \\
\hline $\mathrm{RR}(\mathrm{mm})^{d}$ & 102.4 & 66.9 & 133.0 & 110.8 & 101.0 & 57.2 & 78.6 \\
\hline
\end{tabular}

with ROS. A nonenzymatic peroxidation of ALA takes place that give rise to phytoprostanes (PhytoPs), prostaglandin-like compounds found in plants. ${ }^{10}$ Moreover, recently, a new class of plant oxylipins generated nonenzymatically was reported and called the phytofurans (PhytoFs). ${ }^{11}$

Concerning the physiological role in plants, PhytoPs and PhytoFs have been noticed as signaling molecules, also responsible for the protection of plant cells against negligible reactions triggered under oxidative stress. However, nowadays, there remains a gap on the impact of management practices on their concentration of such molecules as well as on the modification of their levels as a consequence of plant stress. ${ }^{12-14}$ Hence, neither the extent nor the sense in which fertilization modulates the content of oxylipins in plants have been completely explored, as well as their critical impact on plants growth and productivity, despite the accurate description of their occurrence in an array of plant species, which was recently reviewed in detail by Medina et al. ${ }^{15}$

In this context, foliar fertilization could contribute to modify yield and nutritional quality as well as the level of PhytoPs and PhytoFs in plant materials according to the genotype. Thus, although the oxylipins' profiles have been set up in different plant matrices and farming systems (conventional and ecological), a range of irrigation regimes, technological management (plastic cover), and genetic resources, ${ }^{13,16,17}$ to date the influence of a naturalized practice such as fertilization in productive species remains underexplored. In this regard, the present study pursues to shed some light on the response of PhytoPs and PhytoFs in situations of nutritional stress directly related to photosynthesis, at the level of photosystem II (PSII), the intercellular ROS levels, and the genetic differential response of the diverse varieties. In parallel, the information retrieved upon this work will allow the consideration of rice as a source of PhytoPs and PhytoFs in further works in vitro and in vivo devoted at the establishment of bioaccessibility and bioavailability of these compounds as well as their actual biological capacity, in agreement with the information suggested so far by other authors. ${ }^{18-21}$

\section{MATERIALS AND METHODS}

Chemical and Reagents. The PhytoPs 9- $\mathrm{F}_{1 t^{-}}$PhytoP, 9-epi-9- $\mathrm{F}_{1 \mathrm{t}^{-}}$ PhytoP, ent-16- $\mathrm{F}_{1 \mathrm{t}}-\mathrm{Phyto}$, ent-16-epi-16- $\mathrm{F}_{1 \mathrm{t}}-\mathrm{Phyto} \mathrm{P}$, ent-9- $\mathrm{D}_{1 \mathrm{t}}-\mathrm{Phy}-$ toP, ent-9-epi-9- $\mathrm{D}_{1 \mathrm{t}}-\mathrm{PhytoP}, 16-\mathrm{B}_{1}-\mathrm{PhytoP}, 9-\mathrm{L}_{1}-\mathrm{PhytoP}$, and the PhytoFs ent-16-(RS)-9-epi-ST- $\Delta^{14}-10-P h y t o F$, ent-9-(RS)-12-epi-ST$\Delta^{10}$-13-PhytoF, and ent-16-(RS)-13-epi-ST- $\Delta^{14}-9$-PhytoF, were synthesized according to already published procedures and supplied by the Institut des Biomolécules Max Mousseron (Montpellier, France) ${ }^{14}$ Hexane was purchased from Panreac (Castellar del Valles, Barcelona, Spain), and butylated hydroxyanisole (BHA) and Bis-Tris were purchased from Sigma-Aldrich (St. Louis, MO, USA). LC-MS grade solvents were from J.T. Baker (Phillipsburg, NJ, USA). Water was obtained from a milli- $Q$ water purification system from Millipore
(Bedford, MA, USA). The solid phase extraction (SPE) cartridges were acquired from Phenomenex (Torrance, CA, USA).

Field Experiment. The field trial was set up in the Experimental Station "Julio Hirschhorn," located in La Plata $\left(34^{\circ} 52^{\prime} \mathrm{S}, 57^{\circ} 57^{\prime} \mathrm{W}\right.$, $9.8 \mathrm{~m}$ of altitude, Buenos Aires, Argentina) during the seasons 2016/ 2017 and $2017 / 2018$. The soil was featured by $3.7 \%$ of organic matter (Walkey-Black method), $0.2 \%$ of total $\mathrm{N}$ (micro-Kjeldahl method), 18.0 ppm of P (Bray Kurtz method no. 1), and pH 6.2, on average. The panel of rice cultivars included in the present work: one featured by an average grain protein content, which is widely sown by farmers in the production area ('Guri INTA'), one cultivar ('Nutriar FCAyF') characterized by having $30 \%$ more grain protein, and three advanced breeding lines of high grain protein content ('H458-41-1-1-1', 'H4753-1-1-2', and 'H484-9-1') from the "Programa Arroz" of the Agronomy and Forestry Faculty (FCAyF).

The experimental setting was a randomized block design with three replicates. Sowing was done manually in dry land, at a rate of 350 seeds $\mathrm{m}^{-2}$ in grooves at $0.20 \mathrm{~m}$, in plots of $5 \mathrm{~m}^{2}$. The trials were settled with flood irrigation after 30 days of emergence, and weeds were controlled with sodium bispyribac. The treatments were Control and $0.3 \mathrm{~L} \mathrm{ha}^{-1}$ foliar fertilizer (Nutri-Fort) in panicle initiation. The product was diluted in water and applied as a spray and hand sprayed. The experimental plots were sprayed during late afternoon when wind speed was less than $10 \mathrm{~km} \mathrm{~h}^{-1}$. Nutri-Fort contains $7.0 \%$ nitrogen, $2.0 \%$ assimilable phosphorus, $2.2 \%$ soluble potassium, $0.6 \%$ calcium, $1.0 \%$ magnesium, $0.1 \%$ copper, $2.0 \%$ iron, $0.7 \%$ manganese, $\leq 0.1 \%$ zinc, and $1.0 \%$ boron.

The climatic conditions during the field experiment set up are summarized in Table 1 . The trials were sown in November, and the anthesis and harvest were in February and April of the following, respectively. The temperatures recorded during seedling, establishment, and tillering meet the optimum values $\left(25-31^{\circ} \mathrm{C}\right)$, according to previous descriptions, ${ }^{22}$ while during ripening, the temperatures recorded oscillated between 20 and $29^{\circ} \mathrm{C}$.

Samples and Standards Preparation. Harvest and threshing were done manually and, afterward, grains were dried in an oven at 40 ${ }^{\circ} \mathrm{C}$ until reaching $14 \%$ humidity. Dried grains were randomly weighed to record grain weight. Then they were shelled to obtain whole grain. Samples were milled and sieved using a Cyclone mill $0.4 \mathrm{~mm}$ mesh, and they were immediately stored at $4{ }^{\circ} \mathrm{C}$ and protected from light until analysis.

Determination of Protein Content. The protein content was evaluated on dry whole grain flour by micro-Kjeldahl method. Shortly, samples $\left(50 \mathrm{mg}\right.$ ) were digested with $2 \mathrm{~mL}$ of $98 \% \mathrm{H}_{2} \mathrm{SO}_{4}$ and a mixture of potassium sulfate/copper sulfate catalyst (10:1). Then the mixture was heated until complete digestion of the samples and then cooled. Distilled water was added, and steam-distillation of $\mathrm{NH}_{3}$ was carried out by the addition $10 \mathrm{~mL}$ of $40 \%$ sodium hydroxide in water $(\mathrm{w} / \mathrm{v})$ and collected in saturated boric acid solution $\left(40 \mathrm{~g} \mathrm{~L}^{-1}\right)$. The acid neutralized by ammonia was evaluated with standardized $0.02 \mathrm{M}$ $\mathrm{HCl}$, using as indicators methyl red and bromophenol blue. The percentage of nitrogen was calculated using the equation $\%$ nitrogen $=$ $((\mathrm{mL}$ standardized acid $-\mathrm{mL}$ blank $) \times N$ of acid $) \times 1.4007) /$ weight of sample in grams. The F-factor 6.25 was applied for the determination of the protein concentration in rice samples.

Extraction of Phytoprostanes and Phytofurans. The PhytoPs and PhytoFs present in brown rice flours were extracted and cleaned 
Table 2. UHPLC-ESI-MS/MS-QqQ Parameters for the Quantification and Confirmation of Phytoprostanes and Phytofurans in Rice (Oryza sativa L.)

\begin{tabular}{|c|c|c|c|}
\hline compd & retention time $(\mathrm{min})$ & ESI mode & MRM transition $(\mathrm{m} / \mathrm{z})$ \\
\hline \multicolumn{4}{|l|}{ Phytoprostanes } \\
\hline \multirow[t]{2}{*}{ ent-16-epi-16- $\mathrm{F}_{1 \mathrm{t}}-\mathrm{Phyto}^{c}$} & 1.583 & negative & $327.1>283.2^{a}$ \\
\hline & & negative & $327.1>225.1^{b}$ \\
\hline \multirow{2}{*}{ 9- $\mathrm{F}_{1 \mathrm{t}}-\mathrm{PhytoP}$} & 1.631 & negative & $327.2>273.1$ \\
\hline & & negative & $327.2>171.0$ \\
\hline \multirow[t]{2}{*}{ ent-16- $\mathrm{F}_{1 \mathrm{t}}-\mathrm{Phyto}^{c}$} & 1.712 & negative & $327.2>283.2$ \\
\hline & & negative & $327.2>225.1$ \\
\hline \multirow{2}{*}{ 9-epi-9- $\mathrm{F}_{1 \mathrm{t}}$-PhytoP } & 1.785 & negative & $327.2>272.8$ \\
\hline & & negative & $327.2>171.0$ \\
\hline \multirow[t]{2}{*}{ ent-9- $\mathrm{D}_{1 \mathrm{t}}$-PhytoP } & 1.791 & negative & $325.2>307.3$ \\
\hline & & negative & $325.2>134.7$ \\
\hline \multirow[t]{2}{*}{ ent-9-epi-9- $\mathrm{D}_{1 \mathrm{t}}-\mathrm{PhytoP}$} & 2.022 & negative & $325.2>307.2$ \\
\hline & & negative & $325.2>134.9$ \\
\hline \multirow[t]{2}{*}{ 16-B B $_{1}$ PhytoP } & 2.620 & negative & $307.2>223.2$ \\
\hline & & negative & $307.2>235.1$ \\
\hline \multirow[t]{2}{*}{ 9- $\mathrm{L}_{1}$-PhytoP } & 3.079 & negative & $307.2>185.1$ \\
\hline & & negative & $307.2>196.7$ \\
\hline \multicolumn{4}{|l|}{ Phytofurans } \\
\hline \multirow[t]{2}{*}{ ent-9-(RS)-12-epi-ST- $\Delta^{10}-13-P h y t o F$} & 0.906 & negative & $344.0>300.0$ \\
\hline & & negative & $344.0>255.9$ \\
\hline \multirow[t]{2}{*}{ ent-16-(RS)-9-epi-ST- $\Delta^{14}$-10-PhytoF } & 1.501 & negative & $343.9>209.0$ \\
\hline & & negative & $343.9>201.1$ \\
\hline \multirow[t]{2}{*}{ ent-16-(RS)-13-epi-ST- $\Delta^{14}-9$-PhytoF } & 1.523 & negative & $343.0>171.1$ \\
\hline & & negative & $343.0>97.2$ \\
\hline
\end{tabular}

Table 3. Mean Values of Yield $\left(\mathrm{g} \mathrm{m}^{-2}\right)$, 1000-Whole Grain Weight $(\mathrm{g})$, and Protein Content (\% of Dry Matter) in the Five Genotypes upon Two Foliar Fertilization Treatments

\begin{tabular}{|c|c|c|c|c|c|c|c|c|c|}
\hline \multirow[b]{2}{*}{ genotype } & \multicolumn{3}{|c|}{ yield } & \multicolumn{3}{|c|}{ 1000-whole grain weight } & \multicolumn{3}{|c|}{ protein content } \\
\hline & no fertilization & foliar fertilization & $\begin{array}{c}p- \\
\text { value }\end{array}$ & no fertilization & foliar fertilization & $\begin{array}{c}p- \\
\text { value }\end{array}$ & no fertilization & foliar fertilization & $\begin{array}{c}p- \\
\text { value }\end{array}$ \\
\hline 'Guri INTA' & $915.56 \pm 115.92 \mathrm{a}^{a}$ & $955.56 \pm 101.18 a$ & $\mathrm{~ns}^{b}$ & $18.42 \pm 0.12 \mathrm{~d}$ & $18.32 \pm 0.16 \mathrm{~d}$ & ns & $8.8 \pm 0.07 \mathrm{c}$ & $9.3 \pm 0.23 c$ & $*$ \\
\hline 'Nutriar FCAyF' & $840.00 \pm 103.92 \mathrm{a}$ & $860.0 \pm 214.89 a$ & ns & $19.59 \pm 0.06 c$ & $19.48 \pm 0.29 c$ & $\mathrm{~ns}$ & $12.6 \pm 0.21 \mathrm{a}$ & $12.4 \pm 0.51 \mathrm{a}$ & ns \\
\hline 'H458-41-1-1-1' & $963.33 \pm 4.71 \mathrm{a}$ & $1060.0 \pm 113.92 \mathrm{a}$ & ns & $22.81 \pm 0.34 \mathrm{~b}$ & $22.73 \pm 0.08 \mathrm{~b}$ & ns & $11.0 \pm 0.78 \mathrm{~b}$ & $11.0 \pm 0.11 \mathrm{ab}$ & ns \\
\hline 'H475-3-1-1-2’ & $953.33 \pm 81.10 \mathrm{a}$ & $953.33 \pm 59.25 \mathrm{a}$ & ns & $23.98 \pm 0.45 a$ & $23.53 \pm 0.22 \mathrm{a}$ & ns & $10.7 \pm 0.42 b$ & $10.5 \pm 0.13 b c$ & ns \\
\hline $\begin{array}{l}\text { 'H484-9-1' } \\
p \text {-value }\end{array}$ & $\begin{array}{c}966.67 \pm 90.18 \mathrm{a} \\
\mathrm{ns}\end{array}$ & $\begin{array}{c}1144.44 \pm 40.73 \mathrm{a} \\
\mathrm{ns}\end{array}$ & ns & $\begin{array}{c}23.56 \pm 0.44 \mathrm{ab} \\
* * *\end{array}$ & $\begin{array}{c}23.88 \pm 0.16 \mathrm{a} \\
* * *\end{array}$ & ns & $\begin{array}{c}10.3 \pm 0.51 \mathrm{~b} \\
* * *\end{array}$ & $\begin{array}{c}10.0 \pm 1.32 \mathrm{bc} \\
* * *\end{array}$ & $\mathrm{~ns}$ \\
\hline
\end{tabular}

${ }^{a}$ Means \pm SD $(n=3)$ within a column followed by distinct letters are significantly different at $p<0.05$ according to Tukey's multiple range test. The effect of foliar fertilization was compared for each genotype by paired $t$-test. ${ }^{b} \mathrm{~ns}$, not significant; $*, p<0.05 ; * * *, p<0.001$.

up by SPE, following the methodology previously optimized and validated in our own. ${ }^{15,23,24}$ Afterward, samples were reconstituted and filtered through a $0.45 \mu \mathrm{m}$ filter (Millipore, MA USA).

UHPLC-ESI-QqQ-MS/MS Analysis. Chromatographic separation of PhytoPs and PhytoFs was performed using a UHPLC coupled with a 6460 triple quadrupole-MS/MS (Agilent Technologies, Waldbronn, Germany), using the analytical column BEH C18 $(2.1 \mathrm{~mm} \times 50 \mathrm{~mm}$, $1.7 \mu \mathrm{m}$ ) (Waters, Milford, MA). The column temperatures were $6{ }^{\circ} \mathrm{C}$ (both left and right). The mobile phases consisted of Milli-Q-water/ acetic acid (99.99:0.01, v/v) (A) and methanol/acetic acid (99.99:0.01, v/v) (B). The injection volume and flow rate were 20 $\mu \mathrm{L}$ and $0.2 \mathrm{~mL} \mathrm{~min}^{-1}$ upon the following linear gradient (time (min), $\% \mathrm{~B})$ : $(0.00,60.0 \%),(2.00,62.0 \%),(4.00,62.5 \%),(8.00,65.0 \%)$, and (8.01, 60.0\%). An additional post run of $1.5 \mathrm{~min}$ was considered for column equilibration. The spectrometric analysis was conducted in multiple reaction monitoring mode (MRM) operated in negative mode, assigning preferential MRM transition for the corresponding analytes. The ionization and fragmentation conditions were as follows: gas temperature $325{ }^{\circ} \mathrm{C}$, gas flow $8 \mathrm{~L} \mathrm{~min}^{-1}$, nebulizer 30 psi, sheath gas temperature $350{ }^{\circ} \mathrm{C}$, jetstream gas flow $12 \mathrm{~L} \mathrm{~min}^{-1}$, capillary voltage $3000 \mathrm{~V}$, and nozzle voltage $1750 \mathrm{~V}$, according to the most abundant product ions. Data acquisition and processing were performed using Mass Hunter software version B.04.00 (Agilent Technologies). ${ }^{24}$ The quantification of PhytoPs and PhytoFs detected in rice flour was performed using authentic standards according to standard curves freshly prepared as mentioned in the previous section. The selected reaction monitoring and chemical names are referred to in Table 2 and the chemical structures are shown in Supporting Information.

Statistical Analysis. All assays were developed in triplicate $(n=$ 3 ), and concentrations were provided as means \pm standard deviation (SD). To assess the consequence of the foliar fertilization, an analysis of variance (ANOVA) and a multiple range tests (Tukey's test) were carried out using treatment of fertilization and genotypes as sources of variation. It expresses the values of $F$-ratio and $p$-value. The $F$-statistic is a ratio of two variances. The analyses were carried out using IBM SPSS statistics 24.0 (SPSS Inc., Chicago, IL, USA). Significant differences between means were considered at $p<0.05$. 


\section{RESULTS AND DISCUSSION}

To give response to the challenge of the impact of foliar fertilization on yield and quality parameters of rice, as well as on the concentration of PhytoPs and PhytoFs as indicators of plants stress induced by foliar fertilization, crops were set up including two cultivars ('Guri INTA' and 'Nutriar FCAyF') and three advanced breeding lines ('H458-41-1-1-1', 'H475-31-1-2', and 'H484-9-1').

Effect of Foliar Fertilization on Grain Yield and Quality. To understand the behavior of the rice genotypes under study regarding the impact of foliar fertilization on productivity, grain yield, 1000-whole grain weight, and protein content, crops were monitored upon establishment in two consecutive seasons (2016/2017 and 2017/2018). Table 3 shows the detail of these parameters in the five genotypes and two treatments of foliar fertilization. From the results retrieved, it was noticed that for none of the varieties there was significant interaction of fertilization treatment by genotype ( $p$ $>0.05)$, an exception made of the protein content in the variety 'Guri-INTA' that experienced a significant augment from 8.8 to $9.3 \%$ under foliar fertilization.

When comparing yield, 1000-whole grain weight, and protein content of the five genotypes under study, it was found that the average yield under control conditions was $961.22 \mathrm{~g} \mathrm{~m}^{-2}$, being not observed statistically significant differences between genotypes $(p>0.05)$. This trend was also observed when monitoring the effect of foliar fertilization on yield that revealed that, even though the treatment applied increased by $7.2 \%$, the average yields means of all five genotypes, the differences observed were not statistically significant (Table 3). These results are in agreement with most authors that have found positive responses to foliar fertilization. Concerning this, the application of $\mathrm{N}$ concentrated near of panicle initiation was demonstrated as the most efficient practice, which favors the formation of a higher number of spikelets per panicle. ${ }^{25}$ On the other hand, Bhuyan et al. reported yield increases of up to $9.3 \%$ when applying urea, using the technique of foliar fertilizations. ${ }^{26}$ However, although in this regard, it was revealed a clear trend, the present study failed in identifying significant differences as a consequence of foliar fertilization in the two seasons that could be due to the application of the minimum dose recommended by the manufacturer, which could be insufficient.

Regarding 1000-whole grain weight, it was observed that foliar fertilization induced significant differences between genotypes (Table 3 ). Hence, the higher value corresponded to 'H475-3-1-1-2', 'H458-41-1-1-1', and 'H484-9-1' (23.41 g, on average) that surpassed the values recorded for 'Guri-INTA' and 'Nutriar FCAyF" by $19.00 \mathrm{~g}$, on average. These data revealed that grain weight is a phenological feature weakly influenced by the environmental conditions. Indeed, rice grain size is physically restricted by the size of the hull and its weight, under most conditions, and is a very stable varietal feature. ${ }^{27}$ These results were in agreement with Bezerra Barreto et al. that studied the effect of three seasons of application of $\mathrm{N}$ and four doses of $\mathrm{N}$ on five rice cultivars. ${ }^{25}$ Besides, Midorikawa et al. evaluated the effect of the spraying with ammonium chloride on the soil surface at a rate of $8 \mathrm{~g} \mathrm{~m}^{-2}$ on the 'Niponbare' cultivar, and Figueroa studied the effect of Fertideg foliar fertilizer on rice cultivars. ${ }^{28,29}$ From none of these works was it reported differences in the weight of the grains due to the treatments applied. Possibly, the relative contribution of grains per panicle to grain yield is moderate, while that of grain is very low.

The evaluation of the impact of foliar fertilization on the protein content evidenced that only 'Guri INTA' responded to the treatment applied by increasing protein significantly in fertilized plants (by $6.4 \%, p=0.0273$ ) compared to unfertilized controls (Table 3 ). Nowadays, it is already known that foliar fertilization produces contradictory effects regarding protein content in rice grain because it depends on several factors such as the moment of application and the initial nutrition status according to the soil features. ${ }^{5}$ In this regard, several authors have reported critical differences among cultivars featured by an average protein content, as a consequence of foliar fertilization, upon field trials developed in soils with similar composition. $^{28}$ In addition, Bezus et al. and Vidal et al. evaluated genotypes featured by high protein content and did not observe a statistically significant response to the nitrogen fertilization applied. ${ }^{30}$ Additional studies by the same authors evidenced that the response varies according to the genotype, which has been justified because the applied $\mathrm{N}$ can be directed to other destinations different from grain, as yield or biomass, for which it is necessary to evaluate higher doses and other moments of application. ${ }^{30}$

Significant differences were observed between cultivars under both no fertilization and foliar fertilization conditions (Table 3). Genotypes featured by high protein content ('Nutriar FCAyF', 'H458-41-1-1-1', 'H475-3-1-1-2', and 'H484-9-1') presented, on average, $11.1 \% \mathrm{dw}$, while 'Camba INTA' revealed a significantly lower content $(9.1 \% \mathrm{dw})$. Thus, from these results, it was noticed that 'Nutriar FCAyF' was the genotype displaying the highest protein content. Indeed, this variety has been obtained and registered by the Rice Program as a high-protein in grain variety that could contribute to improve the nutritional properties of this cereal.

Total and Individual Phytoprostanes in Rice Grain. The evaluation of the abundance of total PhytoPs in the genotypes studied evidenced that their concentration decreased as follows: 'H475-3-1-1-2' (509.25 $\left.\mathrm{ng} \mathrm{g}^{-1} \mathrm{dw}\right)>$ 'Guri INTA' (396.92 $\mathrm{ng} \mathrm{g}^{-1} \mathrm{dw}$ ) > 'Nutriar FCAyF' (385.23 $\mathrm{ng} \mathrm{g}^{-1}$ $\mathrm{dw})>$ 'H484-9-1' (346.43 $\left.\mathrm{ng} \mathrm{g}^{-1} \mathrm{dw}\right)>$ 'H458-41-1-1-1' (309.16 $\left.\mathrm{ng} \mathrm{g}^{-1} \mathrm{dw}\right)$. In this regard, recently, Pinciroli et al. evaluated the concentration of total PhytoPs in an array of rice varieties by studying 14 genotypes. ${ }^{31}$ Upon this work, the highest concentration of total PhytoPs in whole grain flour corresponded to the variety 'Arborio' and the lowest to 'Itape', with the values 9.51 and $32.89 \mathrm{ng} \mathrm{g}^{-1} \mathrm{dw}$, respectively. Concerning additional plant materials and in order to get a rational understanding on the level of these compounds in rice, it is required to notice the abundance of total PhytoPs in other plant materials. In this regard, to date, the total PhytoPs level has been described in green olives (6.0-87.9 $\mathrm{ng} \mathrm{g}^{-1} \mathrm{fw}$ ), vegetable oils $\left(1.9-119.2 \mathrm{ng} \mathrm{mL}^{-1}\right)$, wines and must (134.12160.0 and $21.4-447.1 \mathrm{ng} \mathrm{mL} L^{-1}$, respectively), and in 24 species of macroalgae $\left(0.1-113.8 \mathrm{ng} \mathrm{g}^{-1} \mathrm{dw}\right),{ }^{17,32-34}$ in three types of raw pecan nuts showed the highest PhytoPs concentration, with a total of $7.8 \mathrm{ng} \mathrm{g}^{-1} \mathrm{fw}$, followed by macadamia (6.5 $\mathrm{ng} \mathrm{g}^{1}{ }^{1} \mathrm{fw}$ ) and walnut (5.5 $\left.\mathrm{ng} \mathrm{g}^{-1} \mathrm{fw}\right){ }^{35} \mathrm{In}$ almond kernels, the total PhytoPs concentration was in the range of $40.0-238.0 \mathrm{ng} \mathrm{g}^{-1} \mathrm{fw}^{16}$ banana passion fruit shell samples (23180 $\left.\mathrm{ng} \mathrm{g}^{-1} \mathrm{dw}\right),{ }^{36}$ in gulupa shell $\left(67.6 \mathrm{ng} \mathrm{g}^{-1} \mathrm{dw}\right)$, and gold berry $21659.8 \mathrm{ng} \mathrm{g}^{-1} \mathrm{dw}^{37}$ The comparison of the level of PhytoPs in the various matrices allowed description of the total amount in rice grains that is in the range of most 
Table 4. Content of Phytoprostanes $\left(\mathrm{ng}^{-1} \mathrm{dw}\right)$ without Significant Interaction Foliar Fertilization Treatment $\times$ Genotype $(p$ $<0.05)^{a}$

\begin{tabular}{|c|c|c|c|c|}
\hline factor & $16-\mathrm{F}_{1 \mathrm{t}}-\mathrm{Phyto} \mathrm{P}+$ ent-16-epi-16- $\mathrm{F}_{1 \mathrm{t}}-\mathrm{Phyto} \mathrm{P}$ & 9-epi-F ${ }_{1 \mathrm{t}}-\mathrm{PhytoP}$ & ent-9-epi-9- $\mathrm{D}_{1 \mathrm{t}}-\mathrm{Phyto} \mathrm{P}$ & ent-9- $\mathrm{D}_{1 \mathrm{t}}-$ PhytoP \\
\hline 'Guri INTA’ & $233.12 \pm 93.99 \mathrm{a}$ & $2.69 \pm 0.29 b$ & $3.43 \pm 1.36 \mathrm{a}$ & $19.98 \pm 3.07 \mathrm{bc}$ \\
\hline 'Nutriar FCAyF' & $217.96 \pm 82.47 \mathrm{a}$ & $2.66 \pm 0.26 b$ & $3.36 \pm 1.87 \mathrm{a}$ & $18.31 \pm 2.15 \mathrm{bc}$ \\
\hline 'H458-41-1-1-1' & $151.45 \pm 57.21 \mathrm{a}$ & $2.83 \pm 1.00 \mathrm{~b}$ & $3.18 \pm 1.25 \mathrm{a}$ & $23.33 \pm 5.79 b$ \\
\hline 'H475-3-1-1-2’ & $254.97 \pm 116.34 a$ & $5.27 \pm 2.05 \mathrm{a}$ & $4.62 \pm 2.01 \mathrm{a}$ & $36.01 \pm 6.10 \mathrm{a}$ \\
\hline 'H484-9-1’' & $209.28 \pm 76.69 \mathrm{a}$ & $1.93 \pm 0.84 \mathrm{~b}$ & $2.60 \pm 0.91 \mathrm{a}$ & $15.68 \pm 2.58 \mathrm{c}$ \\
\hline$F$-ratio ${ }^{p \text {-value }}$ & $1.30^{\text {ns }}$ & $7.84 * * *$ & $1.23^{\mathrm{ns}}$ & $30.42 * * *$ \\
\hline \multicolumn{5}{|c|}{ Foliar Fertilization Treatment } \\
\hline no fertilization & $249.08 \pm 86.07 \mathrm{a}$ & $3.42 \pm 1.77 \mathrm{a}$ & $3.86 \pm 1.66 \mathrm{a}$ & $25.00 \pm 8.82 \mathrm{a}$ \\
\hline foliar fertilization & $177.63 \pm 78.19 b$ & $2.73 \pm 1.26 \mathrm{a}$ & $3.01 \pm 1.41 \mathrm{a}$ & $20.32 \pm 7.19 b$ \\
\hline$F$-ratio ${ }^{p \text {-value }}$ & $5.52 *$ & $2.84^{\mathrm{ns}}$ & $2.04^{\mathrm{ns}}$ & $13.12 * *$ \\
\hline \multicolumn{5}{|c|}{ Interaction Genotype $\times$ Foliar Fertilization Treatment } \\
\hline$F$-ratio ${ }^{p \text {-value }}$ & $0.53^{\mathrm{ns}}$ & $0.41^{\mathrm{ns}}$ & $0.10^{\mathrm{ns}}$ & $0.87^{\mathrm{ns}}$ \\
\hline
\end{tabular}

${ }^{a}$ Means $(n=3)$ within a column followed by distinct letters are significantly different at $p<0.05$ according to Tukey's multiple range test. ns, not significant; $* *, p<0.01 ; * * *, p<0.001$.

Table 5. Content of Phytoprostans $\left(\mathrm{ng} \mathrm{g}^{-1} \mathrm{dw}\right)$ with Significant Interaction Foliar Fertilization Treatment $\times$ Genotype $(p<$ 0.05)

\begin{tabular}{|c|c|c|}
\hline \multirow[b]{2}{*}{ genotype } & \multicolumn{2}{|c|}{ 9- $\mathrm{F}_{1 \mathrm{t}}-\mathrm{PhytoP}$} \\
\hline & no fertilization & foliar fertilization \\
\hline 'Guri INTA’ & $115.36 \pm 15.79 \mathrm{~cd}$ & $110.92 \pm 10.77 \mathrm{~cd}$ \\
\hline 'Nutriar FCAyF' & $121.98 \pm 29.79 \mathrm{bcd}$ & $131.07 \pm 23.71 \mathrm{bc}$ \\
\hline 'H458-41-1-1-1' & $133.29 \pm 7.13 \mathrm{abc}$ & $67.10 \pm 33.12 \mathrm{~d}$ \\
\hline 'H475-3-1-1-2’ & $189.79 \pm 26.81 \mathrm{a}$ & $175.53 \pm 9.85 \mathrm{ab}$ \\
\hline 'H484-9-1' & $128.27 \pm 6.05 b c$ & $82.40 \pm 10.75 \mathrm{~cd}$ \\
\hline$p$-value & $* *$ & $* * *$ \\
\hline
\end{tabular}

\begin{tabular}{cc}
\multicolumn{2}{c}{$16-\mathrm{B}_{1}$-PhytoP } \\
\hline no fertilization & foliar fertilization \\
$18.08 \pm 0.07 \mathrm{ab}$ & $11.37 \pm 1.84 \mathrm{de}$ \\
$9.25 \pm 0.83 \mathrm{ef}$ & $10.22 \pm 0.65 \mathrm{de}$ \\
$18.88 \pm 1.30 \mathrm{a}$ & $13.85 \pm 3.44 \mathrm{~cd}$ \\
$16.58 \pm 1.12 \mathrm{abc}$ & $14.11 \pm 0.21 \mathrm{bcd}$ \\
$7.85 \pm 0.52 \mathrm{ef}$ & $5.89 \pm 1.16 \mathrm{f}$ \\
$* * *$ & $* *$
\end{tabular}

$6.26 * * *$

\begin{tabular}{cc}
\multicolumn{2}{c}{$9-\mathrm{L}_{1}$-PhytoP } \\
\hline no fertilization & foliar fertilization \\
$11.75 \pm 0.24 \mathrm{ab}$ & $7.94 \pm 1.68 \mathrm{cdef}$ \\
$6.37 \pm 0.51 \mathrm{efg}$ & $7.01 \pm 0.56 \mathrm{defg}$ \\
$13.84 \pm 0.76 \mathrm{a}$ & $9.80 \pm 2.80 \mathrm{bcd}$ \\
$11.09 \pm 0.94 \mathrm{abc}$ & $9.66 \pm 0.53 \mathrm{bcde}$ \\
$5.42 \pm 0.58 \mathrm{fg}$ & $4.04 \pm 0.67 \mathrm{~g}$ \\
$* * *$ & $* *$
\end{tabular}

$4.11 * *$

${ }^{a}$ Means $\pm \mathrm{SD}(n=3)$ different letters are significantly different at $p<0.05$ according to Tukey's multiple range test. $* *, p<0.01 ; * * *, p<0.001$. ANOVA multifactor statistic analysis.

vegetable foods (being surpassed only by tropical fruits of high water content and scarce consumption rate), which revealed this matrix as an especially interesting source of PhytoPs in the diet, given the high naturalization in the rice and rice flour diets.

Apart from total PhytoPs, when profiling the individual compounds within this oxylipins class, it was observed the presence of seven individual PhytoPs: $9-\mathrm{F}_{1 \mathrm{t}}-\mathrm{PhytoP}$, ent-16- $\mathrm{F}_{1 \mathrm{t}^{-}}$ PhytoP + ent-16-epi-16- $\mathrm{F}_{1 \mathrm{t}}$-PhytoP, 9-epi-9- $\mathrm{F}_{1 \mathrm{t}}-\mathrm{PhytoP}$, ent-9epi-9- $\mathrm{D}_{1 \mathrm{t}}$-PhytoP, ent-9- $\mathrm{D}_{1 \mathrm{t}}$-PhytoP, 16- $\mathrm{B}_{1}-\mathrm{Phyto}$, and $9-\mathrm{L}_{1^{-}}$ PhytoP (Tables 4 and 5). With respect to the abundance of the individual PhytoPs present in concentrations higher than the limit of quantification, they could be ordered according to lowering average concentrations under control conditions as follows: $16-\mathrm{F}_{1 \mathrm{t}}$-PhytoP + ent-16-epi-16- $\mathrm{F}_{1 \mathrm{t}}-\mathrm{PhytoP}(213.25 \mathrm{ng} /$ $\mathrm{g} \mathrm{dw})>9-\mathrm{F}_{1 \mathrm{t}}$-PhytoP $\left(125.57 \mathrm{ng} \mathrm{g}^{-1} \mathrm{dw}\right)>$ ent-9-epi-D $\mathrm{D}_{1 \mathrm{t}^{-}}$ PhytoP (22.66 ng g $\left.{ }^{-1} \mathrm{dw}\right)>16-\mathrm{B}_{1}-$ PhytoP $\left(12.61 \mathrm{ng} \mathrm{g}^{-1} \mathrm{dw}\right)$ $>$ 9- $\mathrm{L}_{1}$-PhytoP (8.69 $\left.\mathrm{ng} \mathrm{g}^{-1} \mathrm{dw}\right)>9-e p i-9-\mathrm{F}_{1 \mathrm{t}}$-PhytoP (3.44 ng $\mathrm{g}^{-1} \mathrm{dw}$ ) > ent-16-epi-16- $\mathrm{F}_{1 \mathrm{t}}$-PhytoP (3.08 $\mathrm{ng} \mathrm{g}^{-1} \mathrm{dw}$ ) (Tables 4 and 5).

These results were in agreement with previous studies on the level of PhytoPs in a range of rice flours, in which was stated the predominant occurrence of $16-\mathrm{B}_{1}$-PhytoP (52.79 $\mathrm{ng} \mathrm{g}^{-1}$ $\mathrm{dw}$ ), ent-9- $\mathrm{D}_{1 \mathrm{t}}$-PhytoP (28.98 $\mathrm{ng} \mathrm{g}^{-1} \mathrm{dw}$ ), and 9- $\mathrm{L}_{1}$-PhytoP $\left(27.04 \mathrm{ng} \mathrm{g}^{-1}\right)$ in rice bran of the indica subspecies. ${ }^{16} \mathrm{In}$ addition, when evaluating the information available in the literature on the presence of individual PhytoPs in edible and nonedible plant material, it was stated that ent-16- $\mathrm{F}_{1 \mathrm{t}}-\mathrm{PhytoP}$ and ent-16-epi-16- $\mathrm{F}_{1 \mathrm{t}}$-PhytoP were also the most abundant compounds in dry melon leaves $\left(1160.0 \mathrm{ng} \mathrm{g}^{-1}\right)$ and aged wine $\left(133.8 \mathrm{ng} \mathrm{mL}^{-1}\right) .{ }^{13,33}$ On the other hand, in rice grains, $9-\mathrm{F}_{1 \mathrm{t}^{-}}$ PhytoP ranked second, while this PhytoP has been described as the most abundant in olive oil $\left(5.2 \mathrm{ng} \mathrm{mL}^{-1}\right),{ }^{12}$ almonds $\left(42.4 \mathrm{ng} \mathrm{g}^{-1}\right),{ }^{16}$ macroalgae $\left(152.6 \mathrm{ng} \mathrm{g}^{-1}\right),{ }^{34}$ and in grape musts $\left(32.7-13.5 \mathrm{ng} \mathrm{g}^{-1}\right){ }^{33}$ The PhytoPs $16-\mathrm{B}_{1}$-PhytoP and 9- $\mathrm{L}_{1}$-PhytoP resulted in low in carbonic maceration wine $(4.11$ ng $\mathrm{mL}^{-1}$, on average) and macroalgae ( $0.10 \mathrm{ng} \mathrm{g}^{-1}$, on average ), ${ }^{33,34}$ while ent-9-epi-9- $\mathrm{D}_{1 \mathrm{t}}$-PhytoP has been described in low concentrations olive oil and almonds ${ }^{12,16}$ and reported as almost absent in melon leaves. ${ }^{13}$ It is important to notice that certain agronomic and industrial procedures may enhance the PhytoPs content of fruits and derived vegetable oils. In this way, it may be possible to "functionalize" plant products with higher concentrations of these compounds which are readily bioavailable and absorbed by the human body. ${ }^{18}$

The relative abundance of the individual PhytoPs in the plant materials evaluated so far is of special relevance and indicates the challenge of getting a further insight in the biological function of specific classes of PhytoPs, upon dedicated in vivo assays in the frame of animal experimental models and clinical trials. So, it is of special relevance the works developed by Barden et al. that measured, by using GC-MS, the content of $\mathrm{F}_{1}$-PhytoPs in human plasma and urine samples after consuming flaxseed oil for four weeks. ${ }^{19}$ This nutritional trial allowed them to describe an increase of the plasma concentration of $\mathrm{F}_{1}$-PhytoPs; however, the pharmacokinetic 
Table 6. Content of Phytofurans $\left(\mathrm{ng} \mathrm{g}^{-1} \mathrm{dw}\right)$ with and without Significant Interaction Foliar Fertilization Treatment $\times$ Genotype $(p<0.05)$

\begin{tabular}{|c|c|c|c|c|c|c|}
\hline \multirow[b]{2}{*}{ genotype } & \multicolumn{2}{|c|}{ ent-16-(RS)-9-epi-ST- $\Delta^{14}-10-$ PhytoF } & \multicolumn{2}{|c|}{ ent-9-(RS)-12-epi-ST- $\Delta^{10}$-13-PhytoF } & \multicolumn{2}{|c|}{ ent-16-(RS)-13-epi-ST- $\Delta^{14}$-9-PhytoF } \\
\hline & no fertilization & foliar fertilization & no fertilization & foliar fertilization & no fertilization & foliar fertilization \\
\hline 'Guri INTA' & $23.39 \pm 0.87 \mathrm{a}$ & $20.57 \pm 1.79 a$ & $3.91 \pm 0.04 \mathrm{ab}$ & $3.54 \pm 0.38 \mathrm{bc}$ & $11.87 \pm 2.30 \mathrm{abc}$ & $12.74 \pm 1.19 \mathrm{ab}$ \\
\hline 'Nutriar FCAyF' & $21.43 \pm 3.45 \mathrm{a}$ & $19.07 \pm 3.12 \mathrm{a}$ & $4.07 \pm 0.12 \mathrm{ab}$ & $2.90 \pm 0.37 \mathrm{~cd}$ & $14.03 \pm 2.96 \mathrm{a}$ & $10.34 \pm 0.11 \mathrm{abcd}$ \\
\hline 'H458-41-1-1-1' & $25.58 \pm 1.33 \mathrm{a}$ & $18.63 \pm 3.82 \mathrm{a}$ & $4.13 \pm 0.09 \mathrm{ab}$ & $2.79 \pm 0.32 \mathrm{~d}$ & $14.13 \pm 0.77 \mathrm{a}$ & $8.98 \pm 1.62 \mathrm{bcd}$ \\
\hline 'H475-3-1-1-2' & $24.68 \pm 4.01 \mathrm{a}$ & $20.11 \pm 0.48 \mathrm{a}$ & $4.34 \pm 0.10 \mathrm{a}$ & $3.90 \pm 0.14 \mathrm{ab}$ & $9.20 \pm 1.06 \mathrm{bcd}$ & $8.24 \pm 0.71 \mathrm{~cd}$ \\
\hline $\begin{array}{l}\text { 'H484-9-1' } \\
p \text {-value }\end{array}$ & $\begin{array}{c}10.16 \pm 0.73 \mathrm{~b} \\
* * *\end{array}$ & $\begin{array}{c}8.22 \pm 1.26 \mathrm{~b} \\
* * *\end{array}$ & $\begin{array}{c}2.66 \pm 0.06 \mathrm{~d} \\
* * *\end{array}$ & $\begin{array}{c}2.39 \pm 0.30 \mathrm{~d} \\
* *\end{array}$ & $\begin{array}{c}8.45 \pm 0.22 \mathrm{~cd} \\
* *\end{array}$ & $\begin{array}{c}6.78 \pm 0.63 \mathrm{~d} \\
* * *\end{array}$ \\
\hline
\end{tabular}

Interaction Foliar Fertilization Treatment $\times$ Genotypes

F-ratio $^{p \text {-value }} \quad 1.05^{\text {ns }}$

$6.91 * * *$

$4.00 * * *$

${ }^{a}$ Means \pm SD $(n=3)$ different letters are significantly different at $p<0.05$ according to Tukey's multiple range test. ns, no significant interaction; $* *, p<0.01 ; * *, p<0.001$. ANOVA multifactor statistic analysis.

curve and the physiological effects on the human body remain underexplored $^{19}$ and require further characterization in the near future, suggesting that the assessment of new food matrices deserves to be developed to identify optimal dietary sources of these compounds.

Total and Individual Phytofurans in Rice Grain. When profiling PhytoFs in the five varieties of rice included in the present work, the three PhytoFs monitored (ent-16-(RS)-9-epiST- $\Delta^{14}-10-$ PhytoF, ent-9-(RS)-12-epi-ST- $\Delta^{10}-13-$ PhytoF, and ent-16-(RS)-13-epi-ST- $\Delta^{14}-9$-PhytoF) were found in levels higher than the limit of detection of the method (Table 6).

The concentration of PhytoFs decreased as follows: ent-16(RS)-9-epi-ST- $\Delta^{14}$-10-PhytoF (19.18 $\left.\mathrm{ng} \mathrm{g}^{-1} \mathrm{dw}\right)>$ ent-16(RS)-13-epi-ST- $\Delta^{14}$-9-PhytoF (10.48 $\left.\mathrm{ng} \mathrm{g}^{-1} \mathrm{dw}\right)>$ ent-9-(RS)12-epi-ST- $\Delta^{10}-13$-PhytoF (3.46 $\mathrm{ng} \mathrm{g}^{-1} \mathrm{dw}$ ) (Table 6). This decreasing order coincides with that reported by Pinciroli et al. upon the analysis of different types of flour and rice varieties under matching agro-climatic conditions. ${ }^{31}$ Moreover, these data are also in agreement with Yonny et al. that observed ent16-(RS)-9-epi-ST- $\Delta^{14}$-10-PhytoF as the most abundant PhytoF in dry melon leaves, while ent-16-(RS)-13-epi-ST- $\Delta^{14}-9-\mathrm{PhytoF}$ was not detected. ${ }^{13}$ However, when considering the diverse concentration of total PhytoFs in the separate varieties assessed, the following decreasing order of abundance was found: 'Guri INTA' (38.01 ng g ${ }^{-1} \mathrm{dw}$ ) > 'H458-41-1-1-1' $\left(37.11 \mathrm{ng} \mathrm{g}^{-1} \mathrm{dw}\right)>$ "Nutriar FCAyF" (35.92 $\left.\mathrm{ng} \mathrm{g}^{-1} \mathrm{dw}\right)>$ 'H475-3-1-1-2' (35.24 $\mathrm{ng} \mathrm{g}^{-1} \mathrm{dw}$ ) > 'H484-9-1' (19.34 $\mathrm{ng} \mathrm{g}^{-1}$ dw) (Table 6).

To date, there is limited information on the occurrence of PhytoFs in plant materials and vegetable foods concerning both profile and quantitative presence. Among the few articles providing information on this issue, Pinciroli et al. revealed differences between flour types and rice varieties featured by concentrations ranging between $0.06 \mathrm{ng} \mathrm{g}^{-1} \mathrm{dw}$ (for white grain flour obtained of the variety 'Quebracho FA') and 27.70 $\mathrm{ng} \mathrm{g}^{-1} \mathrm{dw}$ (bran rice of the cultivar 'Guri INTA'). ${ }^{31}$ Moreover, Cuyamendous et al. and Yonny et al. reported the occurrence of these compounds in pine, nuts, chia, flaxseeds, and melon leaves in concentrations ranging from 0.30 to $4400.00 \mathrm{ng} \mathrm{g}^{-1}$ dw. ${ }^{13,38}$ However, it has to be noticed that the concentration of PhytoFs in the plant material evaluated has been reported in levels significantly lowers relative to those described for PhytoPs, which could be related with the specific physicochemical features of rice and rice flour, accounting for very low water content.

Influence of Foliar Fertilization in Phytoprostanes and Phytofurans Concentration. When analyzing the effect of foliar fertilization on the concentration of PhytoPs and PhytoFs, it was revealed that this practice modified their concentration significantly, with the exception made of ent-9epi-9- $\mathrm{D}_{1 \mathrm{t}}$-PhytoP that remained unaltered in comparison with no treated controls. Overall, in this work, it was noticed that foliar fertilization causes a decrease of the concentration of plant oxylipins in the five genotypes evaluated.

Similarly, according to diverse authors, PhytoPs and PhytoFs are generated in plant species as a consequence of nonenzymatic peroxidation reactions catalyzed by free radicals (ROS). ${ }^{32}$ Actually, biotic and abiotic stresses alter the balance between the generation of ROS and the scavenging capacity, which entails the disturbance of the redox homeostasis in cells. $^{38}$ In this frame, probably, foliar fertilization could contribute to prevent crops from a situation of nutritional stress. Indeed, increasing evidence suggests that a proper mineral-nutrient status of plants contributes to enhance plants resistance to environmental stress factors. ${ }^{8}$ In addition, according to Cakmak (2002), fertilization increases the antioxidant defense mechanisms, resulting in a reduced photo-oxidation of the chloroplast pigments and the stability of cell membranes. ${ }^{3}$ In this regard, this author suggested that the improvement of the nutritional status of plants, regarding the mineral nutrients $\mathrm{Zn}, \mathrm{K}, \mathrm{Mg}$, and Bo, might contribute to lower the production of ROS and thereby to minimize the activity of NADPH oxidases while maintaining the photosynthetic transport of electrons. ${ }^{3}$ This is further supported by the fact that micronutrients integrate the isoforms of the set of enzymes responsible for detoxification ROS like CuZn-SOD, Mn-SOD, and Fe-SOD. ${ }^{7}$ These antioxidants neutralize ROS, contributing to maintain the integrity of the chloroplast membrane in plants. ${ }^{6}$ This protection from the oxidative damage generated by the adequate supply of minerals could be the cause of the lower generation of oxylipins.

Hence, the quantification of individual PhytoPs in grain of the five rice genotypes, grown under control and foliar fertilization conditions, revealed significantly different concentrations in control plants relative to those fertilized. In this regard, resorting to the analysis of variance, it was observed that foliar fertilization is enclosed to significant and varied effects on the levels of diverse plant oxylipins. Table 4 shows the mean concentrations of the compounds (9-epi-9- $\mathrm{F}_{1 t^{-}}$ PhytoP, ent-9-epi-9- $\mathrm{D}_{1 \mathrm{t}}-$ PhytoP, ent-9- $\mathrm{D}_{1 \mathrm{t}}-\mathrm{Phyto}$, ent-16- $\mathrm{F}_{1 \mathrm{t}}{ }^{-}$ PhytoP + ent-16-epi-16- $\mathrm{F}_{1 \mathrm{t}}$-PhytoP) that did not show significant foliar fertilization $\times$ genotypes interaction in the two seasons. Indeed, these exhibited equal modifications of their concentrations in all genotypes, while the compounds 
featured by a significant foliar fertilization $\times$ genotypes interaction (9- $\mathrm{F}_{1 \mathrm{t}}$-PhytoP, 16- $\mathrm{B}_{1}-$ PhytoP, 9- $\mathrm{L}_{1}-\mathrm{PhytoP}$, ent-9(RS)-12-epi-ST- $\Delta^{10}$-13-PhytoF, ent-16-(RS)-13-epi-ST- $\Delta^{14}$-9PhytoF) are referred to in Table 5.

With respect to the compounds that presented no significant foliar fertilization $\times$ genotype interaction (Table 4 ), the foliar fertilization decreased significantly $(p<0.05)$ the concentration of $16-\mathrm{F}_{1 \mathrm{t}}-\mathrm{PhytoP}+$ ent-16-epi-16- $\mathrm{F}_{1 \mathrm{t}}-\mathrm{PhytoP}$ (from 249.08 to $177.63 \mathrm{ng} \mathrm{g}^{-1} \mathrm{dw}$, on average), 9-epi-9- $\mathrm{F}_{1 \mathrm{t}}$-PhytoP (from 3.42 to $2.73 \mathrm{ng} \mathrm{g}^{-1} \mathrm{dw}$, on average), ent-9-epi-9- $\mathrm{D}_{1 \mathrm{t}^{-}}$ PhytoP (from 3.86 to $3.01 \mathrm{ng} \mathrm{g}^{-1} \mathrm{dw}$, on average), and $9-\mathrm{D}_{1 \mathrm{t}^{-}}$ PhytoP (from 25.00 to $20.32 \mathrm{ng} \mathrm{g}^{-1} \mathrm{dw}$, on average), ent-16(RS)-9-epi-ST- $\Delta^{14}$-10-PhytoF (from 21.05 to $17.32 \mathrm{ng} \mathrm{g}^{-1} \mathrm{dw}$, on average). On average, it was observed a $20.0 \%$ decrease, being ent-16- $\mathrm{F}_{1 \mathrm{t}}-\mathrm{PhytoP}+$ ent-16-epi-16- $\mathrm{F}_{1 \mathrm{t}}-\mathrm{PhytoP}$ (28.7\%, on average) and ent-9-epi-9- $\mathrm{D}_{1 \mathrm{t}}$-PhytoP $(12.0 \%$, on average) the most and less sensitive PhytoPs to foliar fertilization, respectively (Table 4).

For the compounds exhibiting significant foliar fertilization $\times$ genotypes interaction, the genotypes behaved differentially against the application of foliar fertilization (Table 5). The concentration of $9-\mathrm{F}_{1 \mathrm{t}}$-PhytoP decreased as a consequence of the application of foliar fertilization in the advanced line 'H458-41-1-1-1', while for 'Guri INTA', 'Nutriar FCAyF', 'H475-3-1-1-2', and 'H484-9-1', the diminution was not significant. The concentrations of $16-\mathrm{B}_{1}$-PhytoP and $9-\mathrm{L}_{1^{-}}$ PhytoP decreased due to the application of foliar fertilization in 'Guri INTA' and 'H458-41-1-1-1', while in the other genotypes included in this study, no significant modifications were observed (Table 5).

The quantification of individual PhytoFs in the grain of the five rice genotypes revealed different behaviors regarding foliar fertilization $\times$ genotypes interaction. In this respect, ent-16(RS)-9-epi-ST- $\Delta^{14}-10$-PhytoF did not exhibit a significant interaction as its concentration was modified to an equivalent extent in the five genotypes with average values of 21.05 and $17.32 \mathrm{ng} \mathrm{g}^{-1} \mathrm{dw}$ for the unfertilized and fertilized samples, respectively. In contrast, the compounds ent-9-(RS)-12-epi-ST$\Delta^{10}$-13-PhytoF and ent-16-(RS)-13-epi-ST- $\Delta^{14}-9$-PhytoF were affected by significant foliar fertilization $\times$ genotypes interaction (Table 6). Hence, the concentration of ent-9(RS)-12-epi-ST- $\Delta^{10}$-13-PhytoF decreased in 'Nutriar FCAyF' and 'H458-41-1-1-1' genotypes, while ent-16-(RS)-13-epi-ST$\Delta^{14}$-9-PhytoF was only significantly reduced in 'H458-41-1-11 '. In the rest of the genotypes, the concentrations of these compounds were not modified significantly by the application of foliar fertilization. Summarizing the effect of this fertilization approach, the average decrease of the concentrations was by $17.7,18.8$, and $18.4 \%$ for the compounds ent-16-(RS)-9-epiST- $\Delta^{14}$-10-PhytoF, ent-9-(RS)-12-epi-ST- $\Delta^{10}-13-$ PhytoF, and ent-16-(RS)-13-epi-ST- $\Delta^{14}-9-\mathrm{PhytoF}$, respectively.

These results corroborate previous descriptions reporting that some PhytoPs can modify their presence due to stress situations in vivo or to the conditions during storage or processing. ${ }^{14}$ In this regard, in melon leaves exposed to thermal stress, the compound that showed the greatest variations was $9-\mathrm{F}_{1 \mathrm{t}}$-PhytoP. ${ }^{13}$ In addition, the concentration of the compounds 9- $\mathrm{F}_{1 \mathrm{t}}$-PhytoP, 9-epi-9- $\mathrm{F}_{1 \mathrm{t}}-\mathrm{PhytoP}$, and 16- $\mathrm{B}_{1}-\mathrm{Phy}-$ toP in fresh olives was found to increase when the olive trees developed in different situations of water deficit. Likewise, different behaviors were observed for the compounds 9-epi-9$\mathrm{F}_{1 \mathrm{t}}$-PhytoP, 9- $\mathrm{F}_{1 \mathrm{t}}$-PhytoP, 9- $\mathrm{D}_{1}$-PhytoPs, 9-epi-9- $\mathrm{D}_{1 \mathrm{t}}$-Phytops, and $16-\mathrm{B}_{1}$-PhytoP in extract virgin olive (Olea europea $\mathrm{L} \mathrm{cv}$.
Cornicabra) oil between diverse water treatments and even between different seasons (2012 and 2013). ${ }^{14}$ In the same way, ent-9-epi-9- $\mathrm{D}_{1 \mathrm{t}}$-PhytoP and ent-9- $\mathrm{D}_{1 \mathrm{t}}$-PhytoP concentrations in fresh almonds increased during storage. ${ }^{39}$ Thus, seems clear that, so far, there is limited knowledge about the response of plants to diverse environmental situations with respect to the levels of oxylipins.

When evaluating the influence of the genotype on the variation of the concentration of PhytoPs and PhytoFs due to stress, it was noticed that the diverse genotypes showed differences in the concentrations of these compounds as well as in their response to fertilization. Hence, the line 'H475-3-1-1-2' presented high concentrations of most compounds monitored, while the concentration of the treated and untreated samples was not modified, with the only exceptions being 9-epi- $\mathrm{F}_{1 t^{-}}$ PhytoP and ent-9-epi-9- $\mathrm{D}_{1 \mathrm{t}}$-PhytoP. Conversely, line 'H458-411-1-1' showed a decrease in the concentration of the treated samples with respect to those untreated, demonstrating differential genetic response according to the varietal resistance against stress situations. In this regard, Bezerra-Barreto et al. proved that genotypes have different tolerance to nutritional stress. ${ }^{18}$ Both the absorption of nutrients and the effects of their deficiencies can be genotype-dependent. ${ }^{7}$ White and Broadley (2005) reported recent advances in the development of new genotypes with high levels of micronutrients, ${ }^{40}$ suggesting that integration of plant nutrition research with plant genetics and molecular biology is indispensable in developing plant genotypes with high genetic ability to adapt to soils featured by deficient or toxic micronutrient levels and to allocate more micronutrients into edible plant products such as cereal grains. ${ }^{3}$ In addition, to confirm the extensive health benefits of plant oxylipins supported by their chemical structure (similar to prostaglandins and mammalian eicosanoids) and reported in the literature, ${ }^{10,15}$ the advanced line 'H475-3-1-1-2' should be highlighted. Indeed, according to the results retrieved in this work, this is presented as an excellent alternative based on its yields and nutritional quality (Table 3) and according to its high content of PhytoPs and PhytoFs in both fertilized and nonfertilized samples.

In conclusion, this study represents, to the best of our knowledge, the first analysis of the effect of foliar fertilization on the quantitative and qualitative profile of PhytoPs and PhytoFs in rice genotypes. The total content of plant PhytoPs and PhytoFs decreased by 31.9 and $20.0 \%$, respectively, as a result of the foliar fertilization, being revealed as more sensitive to this practice than yield and quality. Taking into account the importance of plant oxylipins concerning the biological functions in higher plants, several studies have shown that they can induce the biosynthesis of additional secondary metabolites as well as to regulate the expression of genes related to detoxification in plants. Deepening the study of oxylipins regarding the metabolism of mineral nutrients and the effect on oxidative stress would allow obtaining rice varieties featured by a greater tolerance to nutritional stress or with a greater efficiency in response to agricultural practices, such as foliar fertilization, giving rise to new management alternatives to mitigate plants damage, for instance, in cases of nutritional deficiency.

On the other hand, early reports have suggested that PhytoPs can show a wide range of interesting biological activities in humans as anti-inflamatory, pro-apoptosis, antiplatelet aggregation, or immuno-regulatory molecules. ${ }^{15}$ If these statements are confirmed by further characterizations, 
this study provides valuable information on how the agricultural practices modulate the level of PhytoPs and PhytoFs and allow obtaining of plant material with specific oxylipins profiles.

\section{AUTHOR INFORMATION}

\section{Corresponding Authors}

*R.D.-P.: phone, +34 968 396200, ext 6247; E-mail, rdperles@ cebas.csic.es.

*A.G.-I.: phone, +34 968 396200, ext 6363; E-mail, angelgil@ cebas.csic.es.

\section{ORCID}

R. Domínguez-Perles: 0000-0001-6232-712X

\section{Funding}

This work was partially funded by the "Fundación Séneca de la Región de Murcia” Grupo de Excelencia 19900/GERM/15 and the Spanish project AGL2017-83386-R from the Spanish Ministry of Science, Innovation and Universities. This work is included in the framework of the collaboration between the Spanish Research Council (CEBAS-CSIC) and CNRS by "Projets Internationaux de Cooperation Scientifique (PICS2015-261141)”. M.P. and R.D.P. were sponsored by a Predoctoral fellowship of the Asociación Universitaria Iberoamericana de Postgrado (RR 631-2016) of the University of Murcia (Spain) and a Postdoctoral Contract (Juan de la Cierva de Incorporación ICJI-2015-25373) from the Ministry of Economy, Industry and Competitiveness of Spain, respectively.

\section{Notes}

The authors declare no competing financial interest.

\section{ACKNOWLEDGMENTS}

We thank the English expert reviewer (Dr. David James Walker) for the revision of the English style and grammar.

\section{ABBREVIATIONS USED}

ALA, $\alpha$-linolenic acid; BHA,butylated hydroxy anisole; PhytoPs,phytoprostanes; PhytoFs,phytofurans; ROS,reactive oxygen species; SPE,solid phase extraction; UHPLC-ESI-QqQ-MS/ MS,ultrahigh performance liquid chromatography coupled to electrospray ionization and triple quadrupole mass spectrometry.

\section{REFERENCES}

(1) Calpe, C. Rice International Commodity Profile; Food and Agriculture Organization (FAO) of the United Nations Markets and Trade Division, 2006; https://www.fao.org/fileadmin/templates/est/ COMM_MARKETS_MONITORING/Rice/Documents/Rice Profile_Dec-06.pdf.

(2) Hirel, B.; Tétu, T.; Lea, P. J.; Dubois, F. Improving Nitrogen Use Efficiency in Crops for Sustainable Agriculture. Sustainability 2011, 3, $1452-1485$.

(3) Cakmak, I. Plant nutrition research: Priorities to meet human needs for food in sustainable ways. Plant Soil 2002, 247, 3-24.
(4) Ata-Ul-Karim, S. T.; Liu, X.; Lu, Z.; Yuan, Z.; Zhu, Y.; Cao, W. In-season estimation of rice grain yield using critical nitrogen dilution curve. Field Crop Res. 2016, 195, 1-8.

(5) Quintero, C.; Zamero, M. A.; Boschetti, G.; Befani, M. R.; Arévalo, E.; Spinelli, N. Momento de aplicación de N y fertilización balanceada de arroz. Fertilizar. 2009, 13, 4-13.

(6) Waraich, E. A.; Ahmad, R.; Ashraf, M. Y. Role of mineral nutrition in alleviation of drought stress in plants. Aust. J. Crop. Sci. 2011, 5, 764-777.

(7) Cakmak, I. Review: Possible roles of zinc in protecting plant cells from damage by reactive oxygen species. New Phytol. 2000, 146, 185205.

(8) Cakmak, I. The role of potassium in alleviating detrimental effects of abiotic stresses in plants. J. Plant Nutr. Soil Sci. 2005, 168 (4), 521-530.

(9) Hayat, S.; Ahmad, A. Salicylic Acid: Biosynthesis, Metabolism, and Physiological Role in Plants. In Salicylic Acid, A Plant Hormone, 1st ed.; Hayat, S., Ahmad, A., Eds.; Springer, 2007; pp 402.

(10) Parchmann, S.; Mueller, M. J. Evidence for the formation of dinor isoprostanes E1 from alpha-linolenic acid in plants. J. Biol. Chem. 1998, 273, 32650-32655.

(11) Cuyamendous, C.; Leung, K. S.; Durand, T.; Lee, J. C. Y.; Oger, C.; Galano, J. M. Synthesis and discovery of phytofurans: metabolites of $\alpha$-linolenic acid peroxidation. Chem. Commun. 2015, 51, 1569615699 .

(12) Collado-González, J.; Pérez-López, D.; Memmi, H.; Gijón, M. C.; Medina, S.; Durand, T.; Guy, A.; Galano, J. M.; Ferreres, F.; Torrecillas, A.; Gil-Izquierdo, A. Water Deficit during Pit Hardening Enhances Phytoprostanes Content, a Plant Biomarker of Oxidative Stress, in Extra Virgin Olive Oil. J. Agric. Food Chem. 2015, 63, 37843792.

(13) Yonny, M. E.; Rodríguez-Torresi, A.; Cuyamendous, C.; Réversat, G.; Oger, C.; Galano, J. M.; Durand, T.; Vigor, C.; Nazareno, M. A. Thermal stress in melon plants: phytoprostanes and phytofurans as oxidative stress biomarkers and the effect of antioxidant supplementation. J. Agric. Food Chem. 2016, 64, 82968304.

(14) Collado-González, J.; Pérez-López, D.; Memmi, H.; Gijón, M. C.; Medina, S.; Durand, T.; Guy, A.; Galano, J.-M.; Fernández, D. J.; Carro, F.; Ferreres, F.; Torrecillas, A.; Gil-Izquierdo, A. Effect of the season on the free phytoprostane content in Cornicabra extra virgin olive oil from deficit-irrigated olive trees. J. Sci. Food Agric. 2016, 96, $1585-1592$

(15) Medina, S.; Gil-Izquierdo, A.; Durand, T.; Ferreres, F.; Domínguez-Perles, R. Structural/Functional Matches and Divergences of Phytoprostanes and Phytofurans with Bioactive Human Oxylipins. Antioxidants 2018, 7, 165-183.

(16) Carrasco-Del Amor, A. M.; Collado-González, J.; Aguayo, E.; Guy, A.; Galano, J. M.; Durand, T.; Gil-Izquierdo, A. Phytoprostanes in almonds: Identification, quantification, and impact of cultivar and type of cultivation. RSC Adv. 2015, 5, 51233-51241.

(17) Collado-González, J.; Moriana, A.; Girón-Moreno, I. F.; Corell, M.; Medina-Escudero, S.; Durand, T.; Guy, A.; Galano, J. M.; Galindo-Egea, A.; Ferreres, F.; Moreno-Lucas, F.; TorrecillasMelendreras, A.; Gil-Izquierdo, A. Effect of deficit irrigation and elaboration process of Spanish-style green table olives on phytoprostanes content in Manzanilla de Sevilla olive flesh. InProceedings of XII Portuguese-Spanish Symposium on Plant Water Relations, Evora, 30 September-3 October, 2014; pp 15.

(18) Durand, T.; Bultel-Poncé, V.; Guy, A.; El Fangour, S.; Rossi, J. C.; Galano, J. M. Isoprostanes and phytoprostanes: Bioactive lipids. Biochimie 2011, 93, 52-60.

(19) Barden, A. E.; Croft, K. D.; Durand, T.; Guy, A.; Mueller, M. J.; MOri, T. A. Flaxseed oil supplementation increases plasma F1phytoprostanes in healthy men. J. Nutr. 2009, 139, 1890-1895.

(20) Gilles, S.; Mariani, V.; Bryce, M.; Mueller, M. J.; Ring, J.; Jakob, T.; Pastore, S.; Behrendt, H.; Traidl-Hoffmann, C. Pollen-derived $\mathrm{E}_{1-}$ phytoprostanes signal via PPAR- $\gamma$ and NF- $\kappa \mathrm{B}$-dependent mechanisms. J. Immunol. 2009, 182, 6653-6658. 
(21) Minghetti, L.; Salvi, R.; Lavinia-Salvatori, M.; Ajmone-Cat, M. A.; De Nuccio, C.; Visentin, S.; Bultel-Poncé, V.; Oger, C.; Guy, A.; Galano, J. M.; Greco, A.; Bernardo, A.; Durand, T. Non enzymatic oxygenated metabolites of $\alpha$-linolenic acid $\mathrm{B}_{1}$ - and $\mathrm{L}_{1}$-phytoprostanes protect immature neurons from oxidant injury and promote differentiation of oligodendrocyte progenitors through PPAR- $\gamma$ activation. Free Radical Biol. Med. 2014, 73, 41-50.

(22) De Datta, S. K. The Climatic Environment and its Effects on Rice Production. In Principles and Practices of Rice Production, 1st ed.; John Wiley and Sons: New York, 1982; pp 642.

(23) Collado-González, J.; Durand, T.; Ferreres, F.; Medina, S.; Torrecillas, A.; Gil-Izquierdo, A. Phytoprostanes. Lipid Technol. 2015, 27, 127-130.

(24) Domínguez-Perles, R.; Abellán, A.; León, D.; Ferreres, F.; Guy, A.; Oger, C.; Galano, J. M.; Durand, T.; Gil-Izquierdo, A. Sorting out the phytoprostane and phytofuran profile in vegetable oils. Food Res. Int. 2018, 107, 619-628.

(25) Bezerra Barreto, J. H.; Soares, I.; Almeida Pereira, J.; Esmeraldo Bezerra, A. M.; Lima de Deus, J. A. Yield Performance of Upland Rice Cultivars at Different Rates and Times of Nitrogen Application. Rev. Bras. Cienc. Solo 2012, 36, 475-483.

(26) Bhuyan, M. H. M.; Ferdousi, M. R.; Iqbal, M. T. Increasing yield and agronomic efficiency of boro rice (Oryza sativa) by fertigation with bed planting compared with conventional planting. Int. J. Agric. Biol. Eng. 2014, 7, 34-47.

(27) Yoshida, S. Rice. In Potential Productivity of Field Crops under Different Environments, 1st ed.; Smith, W. H., Banta, S. J., Ed.; International Rice Research Institute: Los Baños, Phillipines, 1983; pp 534.

(28) Midorikawa, K.; Kuroda, M.; Terauchi, K.; Hoshi, M.; Ikenaga, S.; Ishimaru, Y.; Abe, K.; Asakura, T. Additional Nitrogen Fertilization at Heading Time of Rice Down-Regulates Cellulose Synthesis in Seed Endosperm. PLoS One 2014, 9, e98738.

(29) Figueroa, E. Evaluación Agronómica del Fertilizante Foliar Fertideg NS en Arroz; INTA Mercedes: Corrientes, 2009; http://www. laboratoriosdegser.com/ensayos/Fertideg_foliar09_arroz.pdf.

(30) Vidal, A. A.; Bezus, R.; Pinciroli, M. .; Maiale, S. Evaluación de rendimiento y calidad de grano en genotipos del Programa Arroz de la F.C.A.y F de la UNLP en la zona centro sur de Entre Ríos. Resultados Experimentales, Fundación Proarroz 2006, 15, 45-51.

(31) Pinciroli, M.; Domínguez-Perles, R.; Abellán, A.; Guy, A.; Durand, T.; Oger, C.; Galano, J. M.; Ferreres, F.; Gil-Izquierdo, A. Comparative study of the Phytoprostane and Phytofuran content of indica and japonica rice (Oryza sativa L.) flours. J. Agric. Food Chem. 2017, 65, 8938-8947.

(32) Collado-González, J.; Moriana, A.; Girón, I. F.; Corell, M.; Medina, S.; Durand, T.; Guy, A.; Galano, J. M.; Valero, E.; Garrigues, T.; Ferreres, F.; Moreno, F.; Torrecillas, A.; Gil-Izquierdo, A. The phytoprostane content in green table olives is influenced by Spanishstyle processing and regulated deficit irrigation. Food Sci. Technol. 2015, 64, 997-1003.

(33) Marhuenda, J.; Medina, S.; Diaz-Castro, A.; MartínezHernández, P.; Arina, S.; Zafrilla, P.; Mulero, J.; Oger, C.; Galano, J. M.; Durand, T.; Ferreres, F.; Gil-Izquierdo, A. Dependency of Phytoprostane Fingerprints of Must and Wine on Viticulture and Enological Processes. J. Agric. Food Chem. 2015, 63, 9022-9028.

(34) Barbosa, M.; Collado-González, J.; Andrade, P. B.; Ferreres, F.; Valentão, P.; Galano, J. M.; Durand, T.; Gil-Izquierdo, A. Nonenzymatic $\alpha$-Linolenic acid derivatives from the sea: Macroalgae as novel sources of phytoprostanes. J. Agric. Food Chem. 2015, 63, 64666474.

(35) Carrasco-Del Amor, A. M.; Aguayo, E.; Collado-González, J.; Guy, A.; Galano, J. M.; Durand, T.; Gil-Izquierdo, A. Impact of processing condition of the Phytoprostanes profile of three types of kernel nuts. Free Radical Res. 2017, 51 (2), 141-147.

(36) Medina, S.; Collado-González, J.; Ferreres, F.; LondoñoLondoño, J.; Jiménez-Cartagena, C.; Guy, A.; Durand, T.; Galano, J.M.; Gil-Izquierdo, A. Valorization Strategy of Banana Passion Fruit Shell Wastes: An Innovative Source of Phytoprostanes and Phenolic
Compounds and Their Potential Use in Pharmaceutical and Cosmetic Industries. J. Food Nut. Res. 2017, 5 (11), 801-808.

(37) Medina, S.; Collado-González, J.; Ferreres, F.; LondoñoLondoño, J.; Jiménez-Cartagena, C.; Guy, A.; Durand, T.; Galano, J. M.; Gil-Izquierdo, A. Potential of Physalis peruviana calyces as lowcost resources of phytoprostanes and phenolic compounds. J. Sci. Food Agric. 2018, DOI: $10.1002 /$ jsfa.9413.

(38) Cuyamendous, C.; de la Torre, A.; Lee, Y. Y.; Leung, K. S.; Guy, A.; Bultel-Ponce, V.; Galano, J. M.; Lee, J. C. Y.; Oger, C.; Durand, T. The novelty of phytofurans, isofurans, dihomo-isofurans and neurofurans: Discovery, synthesis and potential application: a review'. Biochimie 2016, 130, 49-62.

(39) Carrasco-Del Amor, A. M.; Aguayo, E.; Collado-González, J.; Guy, A.; Galano, J. M.; Durand, T.; Gil-Izquierdo, A. Impact of packaging atmosphere, storage and processing conditions on the generation of phytoprostanes as quality processing compounds in almond kernels. Food Chem. 2016, 211, 869-875.

(40) White, P. J.; Broadley, M. R. Biofortifying crops with essential mineral elements. Trends Plant Sci. 2005, 10, 586-593. 